\title{
The Fas/CD95 receptor regulates the death of autoreactive $B$ cells and the selection of antigen-specific B cells
}

\section{Gabor Koncz ${ }^{1 *}$ and Anne-Odile Hueber ${ }^{2 *}$}

1 Immunology Research Group of the Hungarian Academy of Sciences, University Eötvös Lorand, Budapest, Hungary

2 Institut de Biologie de Valrose, UMR CNRS 7277, UMR INSERM 1091, Université de Nice-Sophia-Antipolis, Nice, France

\section{Edited by:}

Kong-Peng Lam, Bioprocessing Technology Institute, Singapore

\section{Reviewed by:}

Kong-Peng Lam, Bioprocessing Technology Institute, Singapore Masaki Hikida, Kyoto University, Japan

Shengli Xu, Bioprocessing Technology Institute, Singapore

\section{*Correspondence:}

Gabor Koncz, Immunology research group of the Hungarian Academy of Sciences, University Eötvös Lorand, Pazmany s. 1/C, H-1117 Budapest, Hungary.

e-mail:konczgb@gmail.com; Anne-Odile Hueber, Institut de Biologie Valrose, UMR CNRS 7277 , INSERM 1091, Université de Nice-Sophia Antipolis, Parc Valrose, Bâtiment des Sciences Naturelles, 06108 Nice, France.

e-mail:hueber@unice.fr
Cell death receptors have crucial roles in the regulation of immune responses. Here we review recent in vivo data confirming that the Fas death receptor (TNFSR6) on B cells is important for the regulation of autoimmunity since the impairment of only Fas function on B cells results in uncontrolled autoantibody production and autoimmunity. Fas plays a role in the elimination of the non-specific and autoreactive B cells in germinal center, while during the selection of antigen-specific $B$ cells different escape signals ensure the resistance to Fas-mediated apoptosis. Antigen-specific survival such as BCR or $\mathrm{MHCll}$ signal or coreceptors (CD19) cooperating with BCR inhibits the formation of death inducing signaling complex. Antigen-specific survival can be reinforced by antigen-independent signals of IL-4 or CD40 overproducing the anti-apoptotic members of the Bcl-2 family proteins.

Keywords: cell death, immunity, survival signal

\section{INTRODUCTION}

Apoptosis may be mediated by intrinsic or extrinsic mechanisms. Different stimuli such as irradiation, drugs, cytokine deprivation, DNA damage, anoikis, ER stress, etc., lead to the permeabilization of the mitochondrial membrane, activating the intrinsic pathway. This intrinsic pathway is mainly regulated by the balance and interaction of the pro- and anti-apoptotic proteins of the Bcl-2 family. The combined effect of these different factors determines the amount and the ratio of various members of the Bcl-2 family and regulates mitochondrial depolarization (Elmore, 2007).

The extrinsic pathways are mediated by cell death receptors, including the Fas (CD95/Apo-1/TNFSR6) receptor-ligand system. Upon the engagement of the cell death receptor by FasL, Fas rapidly recruits the adapter molecule FADD and caspase- 8 proenzyme via interactions with the homologous death domain (DD) and death effector domain (DED), forming the deathinducing signaling complex (DISC; Kischkel et al., 1995). This leads to processing and activation of caspase-8, the initiator caspase. Depending on the amount of activated caspase- 8 , this protease can activate the executioner caspases directly (Type-I cells), or indirectly through the cleavage of Bid (Type-II cells), where the truncated form of Bid (tBid) dominates the pro-apoptotic part of the Bcl-2 family, pushing the balance of anti- and pro-apoptotic proteins toward mitochondrial depolarization. In Type-II cells,
Fas-induced cell death can be inhibited by the upregulation of antiapoptotic Bcl-2 proteins, compensating the elevated tBid level. In Type-I cells, induced cell death can be blocked by the downregulation of the number of available receptor molecules (death receptors/decoy receptor ratio), by the regulation of death receptor aggregation, or by FLIP. FLIP, a caspase- 8 homolog (lacking caspase-8's protease activity), can block the FADD-caspase-8 association, inhibiting cell death receptor signaling (Scaffidi et al., 1999).

Evidence accumulated thus far suggests that, apart from the control of death signaling through the number of receptors and oligomerization, anti-apoptotic members of the Bcl-2 family can inhibit the intrinsic pathways in both cell types and only the extrinsic pathways of Type-II cells, while FLIP is able to inhibit only extrinsic pathways, but in both cell types. Pro and pre-B cells as non-activated lymphocytes die principally by intrinsic pathways, chiefly through the upregulation of the Bim pro-apoptotic factor. Accordingly, in these stages of cell development, different survival signals, such as IL7 or BCR tonic signals trigger elevated levels of A1 or Mcl-1 anti-apoptotic proteins of the Bcl-2 family (Opferman, 2008). However, upon antigen recognition, immunoreceptor triggering, cytokines or growth factors (mainly through the regulation of AKT; Suzuki et al., 2003), the Jak-STAT (Khaled and Durum, 2003) pathway, and elevated metabolism (Khan, 2009) strongly push the balance of pro- versus anti-apoptotic members 
of Bcl-2 family toward survival. Therefore activated lymphocytes must be relatively resistant to the intrinsic apoptotic pathway. Non-activated B cells express a minimal amount of Fas. However, upon activation, Fas expression increases. This ensures an additional and necessary break in the regulation of activated $\mathrm{B}$ cells. Simultaneously, with the emergence of potential Type-I cell death, FLIP-mediated blockage of Fas-induced signaling becomes crucial to prevent the unwanted death of activated B cells. With respect to the survival mechanisms against Fas-mediated cell death studied in activated B cells, the number of receptors was not intensively regulated, while the influence of survival signals on receptor oligomerization has not been systematically investigated. Our current knowledge suggests that FLIP is a critical regulator of Fas-mediated B cell death. Elevating FLIP expression results in the quasi conversion from Type-I to Type-II cells (Verbrugge et al., 2010) followed by the upregulation of different anti-apoptotic members of the Bcl-2 family that has been suggested to boost the survival effect of FLIP. In this review, we summarize the different survival signals protecting activated B cells from Fas-induced cell death.

The IAP family proteins mediate another potential mechanism that inhibits different apoptotic routes. These proteins can directly block caspase activation. Their very short half-life keeps the amount of these proteins relatively constant, ensuring the blockage of unwanted caspase activity, but allowing caspase activity from different stimuli. The irregular upregulation of any member of this family ensures the blockage of apoptosis for only a very limited period, explaining why survivals signal rarely regulate the amount of these proteins.

\section{EFFECTS OF B CELL SPECIFIC Fas DEPLETION AND Fas EXPRESSION ON B CELLS: IN VIVO STUDIES}

The interaction between Fas receptor and FasL plays an essential role in the maintenance of immunological tolerance. Lack of function mutations in the Fas receptor (e.g., in lpr mice) or the FasL (gld mice; Takahashi et al., 1994) leads to immune dysfunction in association with particular genetic backgrounds. These include lymphadenopathy, splenomegaly, hyperimmunoglobulinemia, glomerulonephritis, and increased development of B lymphomas (Watanabe-Fukunaga et al., 1992). A similar phenomenon has been observed in human Autoimmune Lymphoproliferative Syndrome (ALPS; Lenardo et al., 2010), most frequently through various mutations in Fas or in other molecules implicated in Fas-mediated signaling (Fisher et al., 1995; Rieux-Laucat et al., 1995).

Historically, the most important role of Fas was reported to be the regulation of $\mathrm{T}$ cell activity. However cell type specific deletion of Fas highlighted its crucial role in the cell death process of different types of cells (including B cells).

Fas was thought to play the main role in $\mathrm{T}$ cell regulation based on the abnormal accumulation of the CD3+ B220+ CD4- CD8$\mathrm{T}$ cell population in lpr mice or mice with $\mathrm{T}$ cell specific depletion of Fas (Stranges et al., 2007). Nevertheless, in B cell specific Fas deficient mice, splenomegaly evolved with age without the appearance of the B220+ DN T cell population (Stranges et al., 2007; Hao et al., 2008). Similarly, the accumulation of both IgM and IgG2a producing autoreactive B cells and increased serum antibody and autoantibody concentrations appear when Fas is specifically deleted in B cells. In contrast, autoantibody production did not occur in T cell specific deletion of Fas (Hao et al., 2004; Stranges et al., 2007). The elevated levels of autoantibodies result in hyperimmunoglobulinemia, vasculitis, and glomerulonephritis (Cohen and Eisenberg, 1991; Shlomchik et al., 1994; Stranges et al., 2007; Hao et al., 2008). The deposition of immune complexes in the kidney, lymphocyte infiltration, and tissue destruction in the liver and lungs leads to lethality in mice of 6-18 months of age in the absence of Fas.

In these mice, in addition to the emergence of B cells, the B cell specific depletion of Fas leads to elevated T cell numbers, as both the exaggerated MHCII expression and the augmented $\mathrm{B}$ cell numbers result in the increased antigen presenting capacity of B cells (Stranges et al., 2007; Hao et al., 2008). An increased number of irregular T cell-B cell interactions are formed, concentrated mainly in the $\mathrm{T}$ cell rich periarteriolar lymphoid sheaths of the spleen (PALS; Jacobson et al., 1995; Stranges et al., 2007; Hao et al., 2008) in lpr mice or in mice with B cell specific Fas deletion (indicating that the number of $\mathrm{B}$ cells is regulated mainly in the $\mathrm{T}$ cell rich area in normal mice).

In transgenic $l p r / l p r$ mice, lymphadenopathy was still observed when functional Fas expression was restored exclusively in B cells. This is due to the expansion of B220+ T cells. However, the serum Ig level was comparable with wild type mice, while the serum level of anti-dsDNA autoantibody was even lower than in normal mice (Komano et al., 1999). Surprisingly, not only was the autoantibody titer limited but antigen-specific responses were also absent, even after secondary immunization against both T-dependent and -independent antigens (Komano et al., 1999). The enhanced death of antigen-specific B cells can be explained by the fourfold greater lytic activity of T cells in lpr mice compared to normal mice due to the higher FasL expression (Chu et al., 1995) and the elevated number of FasL+, DN B220+ T cells in lpr mice (Komano et al., 1999). (However the different localization of this $\mathrm{T}$ cell population and the abnormally developed B cells make us question the role played by DN B220+ T cells in cell death of B cells in lpr/lpr mice; Jacobson et al., 1995). The unwanted death of antigen-specific B cells by exaggerated Fas signaling was confirmed with in vitro experiments, where the "hyperactivation" of Fas with Fc $\gamma$ R bound anti-Fas antibody disabled antigen receptor-mediated survival (Foote et al., 1996b).

In summary, in vivo data indicate that while abnormally intensive Fas/FasL interaction can prevent antigen-specific B cell responses (Komano et al., 1999), the defect in Fas function results in uncontrolled autoantibody production, autoimmunity, and increased risk of B cell lymphomas, revealing that the Fas/FasL balance must be very accurately regulated during the humoral immune response.

B CELL SPECIFIC DEPLETION OF FADD, CASPASE-8, AND FLIP FADD and caspase- 8 are indispensible in Fas-mediated apoptosis. In addition, they contribute to an inhibition of necroptosis, a regulated RIP1- and RIP3-dependent necrotic cell death form (Vandenabeele et al., 2010; Han et al., 2012). An elevated necroptosis due to FADD and caspase- 8 deficiencies is associated with embryonic lethality in mouse. Thus FADD and caspase- 8 deficiencies 
result in a different manifestation from Fas depletion. Blocking the effect of elevated necroptosis in the double knock-out of caspase8 and RIP3 results in viable mice, reminiscent of lpr mice. These mice contain B220+ T cells and show splenomegaly and lymphadenopathy (Oberst et al., 2011) due to abnormally high level of T cells. Not all aspects of B cell response were investigated in doubly knock-out mice. B cell development was normal in RIP and FADD doubly knock-out and the B cells responded normally to stimulation with anti-IgM.

The role of FADD in B cells could not be concluded in FADDknock-out mice due to the organism-wide deficiency. A study using B cell specific FADD knock down demonstrated that FADD depleting had no effect on B cell development in the bone marrow, but resulted in elevated B cell number in the lymphoid organs. Surprisingly the number of B1 cells was significantly reduced (Imtiyaz et al., 2006). B cells collected from $\mathrm{FADD}^{-1-}$ mice were resistant to recombinant FasL-induced cell death in in vitro culture, indicating the indispensible role of FADD in Fas-induced signaling in $\mathrm{B}$ cells. However, despite the essential role of FADD in Fas-induced apoptosis in B cells, mice with B cell specific FADD depletion, even aged, did not exhibit B cell-related autoimmune diseases which are characteristic of Fas deficiency. The BCR- and CD40induced $\mathrm{B}$ cell proliferation was normal in these mice, whereas TLR3 and TLR4 induced proliferation were markedly decreased (Imtiyaz et al., 2006).

B cell specific depletion of caspase- 8 like the absence of FADD resulted in elevated $B$ cell number in the spleen, and reduced amount of B1 cells (Beisner et al., 2005). The BCR, CD40, and CpG-induced proliferation were unaltered, while TLR3 and TLR4generated proliferation was dramatically reduced. Fas-mediated apoptosis was completely abrogated, but the plasma titer produced by the caspase-8-deficient B cells against either the T celldependent or independent antigen was unchanged (Beisner et al., 2005).

Fas-FADD chimera was constructed containing the first 183 amino acids of Fas and the DED of FADD. Expression of this protein in lymphocytes of MRL-lpr/lpr mice completely diminishes their $\mathrm{T}$ cell abnormalities resulting in the disappearance of the unusual $\mathrm{B} 220+\mathrm{T}$ cells representative of Fas deficiencies (Kabra et al., 1999). In contrast to $\mathrm{T}$ cell discrepancies $\mathrm{B}$ cell-related anomalies were not reconstituted by Fas-FADD chimera. Reminiscent to lpr/lpr mice serum antibody level and anti-DNA autoantibody level were higher in Fas-FADD chimera transgenic mice than in normal mice. This indicates that FADDindependent Fas-mediated pathway may operate in B cells, but not in $\mathrm{T}$ cells.

Results observed in B cell specific FLIP-deficient mice indicate that FLIP is dispensable for the development of $\mathrm{B}$ cells in the bone marrow. The numbers of $B$ cells purified from the spleen and lymph nodes of $b$-cflip-deficient mice are significantly reduced when compared with control mice. The data showed that the percentages of B1 cells in the absence of FLIP were lower than in control mice.

While FLIP-deficient B cells can be stimulated with anti-IgM or CD40 to proliferate, this proliferative response cannot be sustained due to the rapid onset of apoptosis (Coffey and Manser, 2010).
B cells lacking FLIP were more sensitive to Fas-induced apoptosis and their participation in the formation of GC responses was inhibited (Zhang et al., 2009; Coffey and Manser, 2010).

The levels of TNP-specific Ig in FLIP-deficient mice were lower than in control mice immunized with either the $\mathrm{T}$ cellindependent or the $\mathrm{T}$ cell-dependent antigens. In summary FLIP plays crucial role of Fas-mediated apoptosis in B cells, as well as in the regulation of $\mathrm{B}$ cell number, and in the survival of antibody producing B cells.

\section{FUNCTION OF Fas IN THE GERMINAL CENTER}

The most unambiguous appearance of Fas is within the activated B cells of germinal centers (GCs; Rathmell and Goodnow, 1995; Liu et al., 1997; Wang and Watanabe, 1999; Mizuno et al., 2003), while the expression and function of Fas on other B cells is highly questionable (Table 1). It is well accepted that Fas expression is markedly upregulated in activated germinal center B cells both in mouse and human systems. Fas expression of lymph node or spleen B cells in vitro and in vivo is markedly increased by PKW, LPS, and ConA activated T cells and mainly by the CD40L (Mandik et al., 1995; Onel et al., 1995; Rothstein et al., 1995; Wang et al., 1996).

Besides the data on Fas expression, functional investigations confirm that Fas plays a crucial role in GC B cells. Specific deletion of Fas from GC B cells produces B cell-related discrepancies documented in lpr mice or in mice with general B cell depletion of Fas, like elevated serum antibody titer, splenomegaly, lymphoadenopathy without the appearance of abnormal DN T cell population (Hao et al., 2008). The elevated B cell number was created mainly by CD38+ memory B cells rather than naive or GC B cells.

In GCs during $\mathrm{T}$ cell-dependent immune response, antigen recognition by $\mathrm{B}$ cells is linked with $\mathrm{T}$ cells that recognize the same antigen (Figure 1). The successful presentation of the B cell's antigen strengthens the $\mathrm{T}$ cell/B cell interaction, which transduces long-term, direct signaling between the two cells. Because CD40L expression on T cells appears within a few minutes following antigen stimulation (van Kooten and Banchereau, 2000), the CD40L-CD40 receptor pair will trigger the B cells to express Fas. CD40 signals launch B cell proliferation, differentiation, germinal center development, isotype switching, etc. (reviewed in Bishop and Hostager, 2003). In addition to inducing Fas expression, CD40 signals provide a potential restraining mechanism to prevent the hyperactivity of humoral immune responses. In the following parts of this review we will summarize the survival signals rescuing the germinal center B cells from Fas-mediated cytotoxicity (Figure 2).

\section{ANTIGEN-SPECIFIC SURVIVAL SIGNALS AND INHIBITION OF Fas-INDUCED CELL DEATH \\ BCR}

The FasL-induced stimulation by antigen-specific T cells can kill germinal center B cells unless a survival signal is received. The main rescue signal is transduced by BCR upon recognition of the antigen (extensively reviewed in Wang and Watanabe, 1999; Rothstein, 2000; Mizuno et al., 2003), such that Fas can only induce cell death in B cells with an impaired BCR signaling capacity or 
Table 1 | Expression and function of Fas and sensitivity to Fas-induced cell death in different B cell populations.

\begin{tabular}{|c|c|c|c|}
\hline Cell type & & Human & Mouse \\
\hline \multirow[t]{2}{*}{ B1 cells } & Expression & $\begin{array}{l}\text { Negative, CD40 stimulation upregulates Fas } \\
\text { expression and induces a biphasic profile (Huck et al., } \\
\text { 1998; Kodama et al., 2001) }\end{array}$ & $\begin{array}{l}\text { Negative, LPS stimulation upregulates Fas expression } \\
\text { (Mandik et al., 1995) and induces a biphasic profile (Hirose } \\
\text { et al., 1997; reviewed in Wang and Watanabe, 1999) }\end{array}$ \\
\hline & Function & Biphasic sensitivity (Kodama et al., 2001) & $\begin{array}{l}\text { Hardly susceptible (Masuda et al., 1997), Function in } \\
\text { autoantibody production in Ipr mice (Watanabe et al., 2002; } \\
\text { Qian et al., 2006) biphasic sensitivity (Hirose et al., 1997) }\end{array}$ \\
\hline \multirow[t]{2}{*}{ Mantle zone } & Expression & $\begin{array}{l}\text { Negative, inducible? (Leithauser et al., 1993; Moller } \\
\text { et al., 1993; Yoshino et al., 1994; Tsunoda et al., 2000) }\end{array}$ & No data \\
\hline & Function & $\begin{array}{l}\text { Participation in autoantibody production (Qian et al., } \\
\text { 2006) }\end{array}$ & No data \\
\hline \multirow{2}{*}{$\begin{array}{l}\text { Pre, pro, } \\
\text { immature }\end{array}$} & Expression & Weak (Nishiuchi et al., 1996; Nilsson et al., 2000) & Weak, positive (Mandik et al., 1995; Onel et al., 1995) \\
\hline & Function & $\begin{array}{l}\text { Resistant (Nishiuchi et al., 1996; Nilsson et al., 2000) } \\
\text { debated in Lanvin et al. (2003) }\end{array}$ & Resistant (Mandik et al., 1995; Onel et al., 1995) \\
\hline \multirow[t]{2}{*}{ Blood } & Expression & $\begin{array}{l}\text { 5-25\% positive (Miyawaki et al., 1992; Daniel and } \\
\text { Krammer, 1994), PKW (Daniel and Krammer, 1994; } \\
\text { Yoshino et al., 1994), IL2 + algM induces (Huck et al., } \\
\text { 1998) }\end{array}$ & Partially positive, LPS induces (Wang et al., 1996) \\
\hline & Function & $\begin{array}{l}\text { Resistant (Yoshino et al., 1994) sensitive upon } \\
\text { upregulation (Daniel and Krammer, 1994) }\end{array}$ & Resistant (Wang et al., 1996) \\
\hline \multirow[t]{2}{*}{ Memory } & Expression & $\begin{array}{l}\text { Low positivity (Liu et al., 1995; Choe et al., 1996; } \\
\text { Lagresle et al., 1996) }\end{array}$ & Low positivity (Tsunoda et al., 2000; Takahashi et al., 2001) \\
\hline & Function & $\begin{array}{l}\text { Resistant (Liu et al., 1995; Choe et al., 1996; Lagresle } \\
\text { et al., 1996; high BCL-2 expression) }\end{array}$ & $\begin{array}{l}\text { Resistant (Tsunoda et al., 2000; Takahashi et al., 2001; high } \\
\text { BCL-2 expression) }\end{array}$ \\
\hline \multirow[t]{2}{*}{ Plasma cells } & Expression & $\begin{array}{l}\text { Tonsil: positive (Choe et al., 1996), negative (Moller } \\
\text { et al., 1993; Merville et al., 1996) in bone marrow: } \\
\text { weakly positive (Nishiuchi et al., 1996) }\end{array}$ & $\begin{array}{l}\text { Weak positivity upon immunization in spleen (Smith et al., } \\
\text { 1995) }\end{array}$ \\
\hline & Function & $\begin{array}{l}\text { Leukemia or myeloma cells unclear results (Shima } \\
\text { et al., 1995; Sampalo et al., 2000) }\end{array}$ & No data \\
\hline
\end{tabular}

For germinal center cells, see the text.

diminished antigen recognition. In accordance with the theory regarding the regulation of $\mathrm{B}$ cell homeostasis, the Fas receptor induces cell death in tolerant B cells upon the desensitization of BCR signaling (Goodnow, 1996) and plays a role in the elimination of the non-specific and autoreactive B cells, generated by somatic mutations that take place in the germinal center (Takahashi et al., 2001; Hao et al., 2008; Ait-Azzouzene et al., 2010) (Figure 1). This selection process will lead to the death of the non-specific or non-responsive (anergic) B cells (Rathmell et al., 1995, 1996; Rothstein et al., 1995), while specific B cells become plasma cells, memory cells, or re-enter into the germinal center cycle again.

Different signaling pathways were considered regarding the regulation of the BCR-transduced survival signals (Table 2).

\section{MHC II}

Beside antigen recognition by B cells, TCR-MHC interaction requires the specificity of the adaptive immune response. $\mathrm{B}$ cells are effective antigen presenting cells capable of initiating cell-cell interactions with $\mathrm{T}$ cells. In the B cell-T cell pair TCR-MHCinteractions ensure the common specificity of the two cells, guaranteeing that the correct antigen is presented to the specific $\mathrm{T}$ cells. Without BCR-mediated uptake, processing, and presentation of the adequate antigen by B cells long-term B cell-T cell linkage cannot be created. The prolonged $\mathrm{T}$ cell-B cell interaction also increases the potential Fas-FasL interaction time. The importance of the antigen presentation in Fas-mediated cell death of B lymphocytes was clearly confirmed when peptide fragments of HEL antigen were loaded into B cells. Since B cells recognized only the whole antigen and not the fragments the BCR-transduced survival was inactive, but the antigen presenting capacity remained normal with respect to the peptide specific $\mathrm{T}$ cells. In this model, antigen presenting B cells were killed by the HEL specific T cells. Without the peptide loading (without the antigen presenting capacity), the B cells survived (Rathmell et al., 1996; Janssens et al., 2003).

Beyond the ability to trigger the $\mathrm{T}$ cells, MHCII is capable of transducing its own (reverse) signals, and consequently triggering B cell activation (Scholl and Geha, 1994; Al-Daccak et al., 2004). Several studies investigated the effect of MHCIImediated signaling on Fas-induced apoptosis, but the impact of MHCII-transduced signals on Fas-induced cell death is debated. 


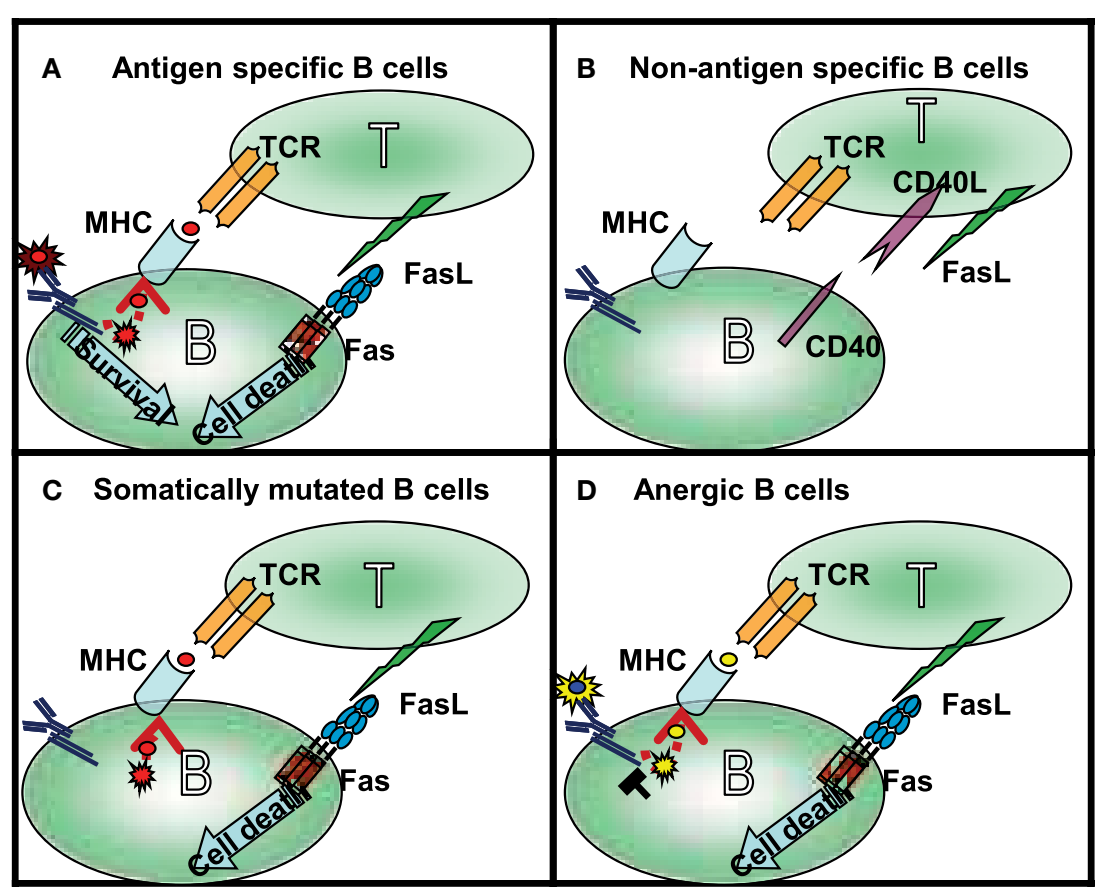

FIGURE 1 | Four different types of T cell-B cell interaction can occur in the germinal center: (A) following antigen recognition the specific $B$ cells express Fas and in time became capable of presenting antigen to antigen-specific $T$ cells. Strong affinity B cells maintain their antigen specificity during somatic mutation and as a consequence the BCR transduces signals even during competition for the limited available antigen. The BCR-mediated survival signals compete with Fas-induced cell death. (B) The naive (bystander) B cells do not interact with activated, FasL-expressing $T$ cells in the absence of presentation of the appropriate antigen. In this situation their Fas expression is also very limited. As mentioned above, these cells are not targets of Fas-induced cell death. (C) The low affinity B cells, and $B$ cells which lost antigen-specificity because of somatic mutation, are first targets of Fas-mediated killing. Maintaining antigen presenting capacity, but losing antigen triggering in the competition for the antigen, these cells contact the T cells, but do not access the survival signal. This explains the elevated antibody level in Ipr mice where the antigen non-specific B cells can survive. (D) Anergic B cells are the main targets of Fas-mediated killing; the antigen receptor signaling of anergic $B$ cells is desensitized due to their permanent activation. This group can explain the enhanced autoantibody production observed in Ipr mice.

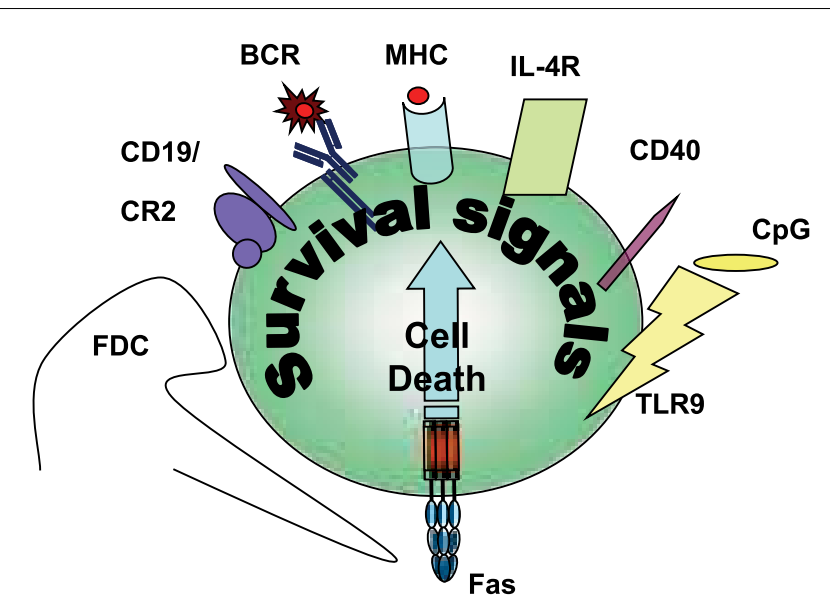

FIGURE 2 | Survival signals rescuing Fas-induced apoptosis in B cells.

Using different cell lines, pre-treatment with agonistic anti-MHCII antibodies before anti-Fas addition enhances the cell death intensity in case of immature and blastoid B cell lines, but has no effect on plasmacytic cell lines (Yoshino et al., 1995; Blancheteau et al.,
2002). In contrast, results obtained with mouse spleen B cells and the A20 B cell line indicate that simultaneous MHCII signals with Fas triggering protect the B cells from Fas-stimulated cell death (Catlett et al., 2001), but 24-96 h pre-treatment of anti-MHCII increased the Fas-mediated cell death, at least partially because, surprisingly, it induced FasL expression on the B cells (Truman et al., 1997).

Due to the divergent functional data, conflicting results have been published concerning the effect of MHCII on the Fasmediated signaling pathway (Table 2). In A20 mouse B cell line, the MHCII signal had no influence on Fas/Fadd association, but reduced the caspase- 8 activity and cell death (Catlett et al., 2001). In contrast on LAD human B cell line, a 30-min pre-treatment of MHCII by enhancing the FADD recruitment to the Fas receptor, augments the caspase cleavage and cell death (Blancheteau et al., 2002). Regrettably all above experiments were performed by usage of anti-MHCII antibodies, without studying the direct T cell-B cell connection.

\section{CORECEPTORS}

Accumulated evidence suggests that other signals that are not directly implicated in antigen recognition may modify the BCRmediated survival. CD19, a positive coreceptor of the BCR, reduces 
Table 2 | Detailed molecular mechanism of inhibition of Fas-induced cell killing.

\begin{tabular}{|c|c|c|c|c|c|c|c|}
\hline & BCR & MHCII & CD19 & CD40 & IL-4 & FDC & CpG \\
\hline Fas expression & $\begin{array}{l}\text { Unchanged/increased } \\
\text { (Garrone et al., 1995; } \\
\text { Rathmell et al., 1995; } \\
\text { Rothstein et al., 1995; Foote } \\
\text { et al., 1996b; Nakanishi et al., } \\
\text { 1996; Bras et al., 1997; } \\
\text { Schneider et al., 1997; } \\
\text { Tumang et al., 2002; Schram } \\
\text { and Rothstein, 2003; } \\
\text { Moriyama and Yonehara, } \\
\text { 2007) } \\
\text { Decreased (Choe et al., 1996; } \\
\text { Lagresle et al., 1996) }\end{array}$ & $\begin{array}{l}\text { Not altered } \\
\text { Yoshino et al., } \\
\text { 1995; Catlett } \\
\text { et al., 2001; } \\
\text { Blancheteau } \\
\text { et al., 2002) }\end{array}$ & $\begin{array}{l}\text { Not decreased } \\
\text { (Barrington } \\
\text { et al., } \\
\text { 2005)/decreased } \\
\text { (Mongini } \\
\text { et al., 2003) }\end{array}$ & $\begin{array}{l}\text { Upregulated } \\
\text { (Garrone et al., } \\
\text { 1995; Lagresle } \\
\text { et al., 1995; } \\
\text { Onel et al., } \\
\text { 1995; Rathmell } \\
\text { et al., 1995; } \\
\text { Schattner } \\
\text { et al., 1995; } \\
\text { Wang et al., } \\
\text { 1996) }\end{array}$ & $\begin{array}{l}\text { Unchanged/ } \\
\text { increased } \\
\text { (Foote et al., } \\
\text { 1996a; } \\
\text { Koizumi et al., } \\
\text { 1996; } \\
\text { Nakanishi } \\
\text { et al., 1996; } \\
\text { Wurster et al., } \\
\text { 2002) }\end{array}$ & $\begin{array}{l}\text { Upregulated } \\
\text { (Tsunoda et al., } \\
\text { 2000) }\end{array}$ & $\begin{array}{l}\text { Decreased } \\
\text { Wang et al., } \\
\text { 1997) } \\
\text { Not decreased } \\
\text { (Hancz et al., } \\
\text { 2012) }\end{array}$ \\
\hline DISC level & $\begin{array}{l}\text { Reduced (Catlett and Bishop, } \\
\text { 1999)/not changed (Carey } \\
\text { et al., 2000; Wang et al., } \\
\text { 2000) FADD association } \\
\text { Reduced caspase-8 } \\
\text { association Mang et al., } \\
\text { 2000) } \\
\text { Reduced caspase-8 cleavage } \\
\text { (Bras et al., 1997; Catlett and } \\
\text { Bishop, 1999; Hinshaw et al., } \\
\text { 2003; Moriyama and } \\
\text { Yonehara, 2007) } \\
\text { Transient upregulation of FLIP } \\
\text { Mang et al., 2000; Hennino } \\
\text { et al., 2001; Owyang et al., } \\
\text { 2001; Schram and Rothstein, } \\
\text { 2003; Moriyama and } \\
\text { Yonehara, 2007) } \\
\text { FLIP silencing leads to Fas } \\
\text { sensitivity (Moriyama and } \\
\text { Yonehara, 2007) } \\
\text { FLIP overexpression leads to } \\
\text { resistance Mang et al., 2000) }\end{array}$ & $\begin{array}{l}\text { Reduced } \\
\text { caspase-8 } \\
\text { activity (Catlett } \\
\text { et al., 2001) } \\
\text { Elevated } \\
\text { caspase-8 } \\
\text { cleavage } \\
\text { (Blancheteau } \\
\text { et al., 2002) }\end{array}$ & $\begin{array}{l}\text { Reduced } \\
\text { caspase-8 } \\
\text { cleavage } \\
\text { (Mongini } \\
\text { et al., 2003) } \\
\text { Upregulation } \\
\text { of FLIP } \\
\text { (Mongini et al., } \\
\text { 2003; } \\
\text { Barrington } \\
\text { et al., 2005) }\end{array}$ & $\begin{array}{l}\text { Not changed } \\
\text { Fadd } \\
\text { association } \\
\text { (Benson et al., } \\
\text { 2006; Eeva } \\
\text { et al., 2007) } \\
\text { Decreased } \\
\text { caspase-8 } \\
\text { activation } \\
\text { (Benson et al., } \\
\text { 2006; Eeva } \\
\text { et al., 2007) } \\
\text { Flip expression } \\
\text { is upregulated } \\
\text { (Hennino } \\
\text { et al., 2000, } \\
2001 \text {; Eeva } \\
\text { et al., 2007) }\end{array}$ & & $\begin{array}{l}\text { Reduced } \\
\text { caspase-8 } \\
\text { activity (van } \\
\text { Eijk et al., } \\
2001 \text { b) without } \\
\text { FDC FLIP } \\
\text { expression } \\
\text { decays } \\
\text { (Hennino } \\
\text { et al., 2001) } \\
\text { presence of } \\
\text { FDC restore } \\
\text { FLIP } \\
\text { expression } \\
\text { (van Eijk et al., } \\
2001 \text { b) }\end{array}$ & $\begin{array}{l}\text { Reduced } \\
\text { caspase-8 } \\
\text { activity (Hancz } \\
\text { et al., 2012) }\end{array}$ \\
\hline Mitochondria & $\begin{array}{l}\text { Transient upregulation of } \\
\text { Bcl-xl (Choe et al., 1996; } \\
\text { Koizumi et al., 1996; } \\
\text { Schneider et al., 1997; } \\
\text { Owyang et al., 2001; Tumang } \\
\text { et al., 2002; Schram and } \\
\text { Rothstein, 2003) } \\
\text { Bfl-1 upregulation (Tumang } \\
\text { et al., 2002) } \\
\text { Effective survival without } \\
\text { upregulation of Bcl-xl (Alam } \\
\text { et al., 1997; Owyang et al., } \\
2001 \text {; Hinshaw et al., 2003; } \\
\text { Moriyama and Yonehara, } \\
\text { 2007) } \\
\text { Overexpression of Bcl-xl does } \\
\text { not display absolute survival } \\
\text { (Schneider et al., 1997) }\end{array}$ & & $\begin{array}{l}\text { Upregulation } \\
\text { of Bcl-2 } \\
\text { (Mongini et al., } \\
2003 \text { ) } \\
\text { Bcl-2 was not } \\
\text { changed in } \\
\text { (Barrington } \\
\text { et al., 2005) }\end{array}$ & $\begin{array}{l}\text { Bfl-1, A1, } \\
\text { Bcl-xl } \\
\text { upregulated } \\
\text { (Lee et al., } \\
\text { 1999) }\end{array}$ & $\begin{array}{l}\text { Upregulated } \\
\text { Bcl-xl Wurster } \\
\text { et al., 2002) } \\
\text { marginal Bcl-xl } \\
\text { upregulation } \\
\text { (Schneider } \\
\text { et al., 1997) }\end{array}$ & $\begin{array}{l}\text { Bcl-2, Bcl-xl, } \\
\text { Bax amount } \\
\text { was } \\
\text { unchanged } \\
\text { (Schwarz et al., } \\
\text { 1999; Tsunoda } \\
\text { et al., 2000) }\end{array}$ & \\
\hline
\end{tabular}


Table 2 | Continued

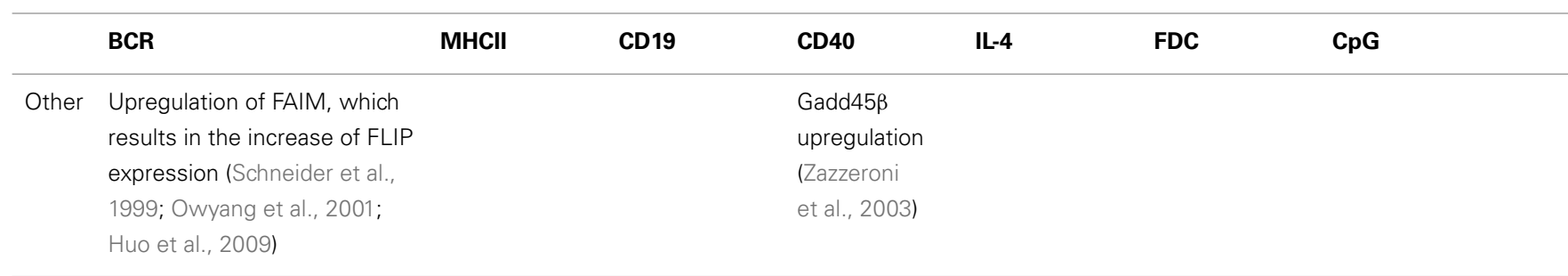

Bold font, human; normal font, mouse.

Human: BCR (Garrone et al., 1995; Choe et al., 1996; Lagresle et al., 1996; Hennino et al., 2001; Alam et al., 1997), MHC (Yoshino et al., 1995; Blancheteau et al., 2002), CD19 (Mongini et al., 2003), CD40 (Garrone et al., 1995; Lagresle et al., 1995; Schattner et al., 1995; Benson et al., 2006; Hennino et al., 2000; Lee et al., 1999; Hennino et al., 2001), FDC (Tsunoda et al., 2000; van Eijk et al., 2001b; Hennino et al., 2001).

the required threshold for B cell activation. Published data indicate that either positive (CD19) or negative coreceptors (Fc $\gamma$ RIIb, CD22) modify the strength or the threshold of the BCR signaling. Among them, the effect of CD19, the signaling part of complement receptor 2 (CD21) was studied as a regulator of Fas-induced cell death. It is well known that coactivation of BCR with CD19 reduces the threshold of anti-IgM signaling 10- to 100-fold (Carter and Fearon, 1992), attracting attention to the importance of the complement system in the immune complex. In accordance with these results, recombinant antigen fused with the $\mathrm{C} 3 \mathrm{~d}_{3}$ complement component reduced 100-fold the amount of antigen necessary for $50 \%$ protection against anti-Fas-induced cell death (Barrington et al., 2005). Further confirming the role of complement fragments in survival signals, increased apoptosis was observed in $\mathrm{CR} 2^{-/-} \mathrm{B}$ cells, but not in CR2 ${ }^{-/-}$lpr mice (Barrington et al., 2005). The intensively triggered CD21 alone is capable of generating partial survival (Mongini et al., 2003) and co-stimulation of the anti-CD21 with anti-IgM enhancing protection against Fasinduced cell death (Mongini et al., 2003). The exact signaling of this effect is not clear (Table 2). Coactivation of CD21 and BCR in human tonsillar B cells decreased Fas expression upon CD40 stimulus, increase the levels of anti-apoptotic Flip and Bcl-2 (but not BCL-xl) and reduced caspase- 8 cleavage when compared to BCR activation alone (Mongini et al., 2003) However activation of mouse $B$ cells by recombinant antigen fused with $C 3 \mathrm{~d}_{3}$ resulted in only an increase in expression level of FLIP but not Bcl-2. Similarly antigen stimulation of CR2 ${ }^{-1-}$ mice resulted in normal Fas expression and reduced amount of FLIP but not BCL-2 (Barrington et al., 2005).

\section{NON-ANTIGEN-SPECIFIC SURVIVAL SIGNALS}

Antigen-independent (non-specific) B cells, in which activating signals do not markedly alter the balance of anti- and proapoptotic proteins toward survival, can be a target of Bcl-2 regulated escape from Fas-induced cell death.

\section{CD40}

CD40 is one of the most important coreceptors of B cells, playing a crucial role in the stimulation of $\mathrm{B}$ cell proliferation, inducing somatic mutation and class switch. The main source of the B cell stimulating CD40L is derived from activated T cells, but dendritic cells and germinal center B cells (Grammer et al., 1995, 1999) also carry the ligand. Upon triggering, CD40 upregulates
Fas expression in both naive, germinal center, and memory B cells and facilitates the apoptotic death of stimulated cells. CD40L is fully involved in the induction of Fas in anergic B cells. In specific $\mathrm{B}$ cells, due to the more intensive BCR signaling, CD40L is only partially responsible for Fas upregulation (Rathmell et al., 1996). Besides Fas upregulation, the CD40L-induced stimulus, alone (Cleary et al., 1995; Hennino et al., 2000), or synergistically with the BCR signal (Koopman et al., 1997; Lee et al., 1999; Hennino et al., 2000; Zazzeroni et al., 2003; Ho et al., 2005; Kater et al., 2005; Benson et al., 2006; Eeva et al., 2007), provides a short term ( 1 to maximum 2 days) rescue signal against Fas-induced death (reviewed in Guzman-Rojas et al., 2002). Several publications explain this survival signal (Table 2).

1. The assembly of DISC in mouse and human B cell lines is regulated by CD40 signals. Resembling the BCR-mediated survival signal several articles presented that CD40 stimulation decreased the caspase- 8 and caspase- 3 activation, and the collapse of mitochondrial membrane potential but did not affect FADD-Fas association (Benson et al., 2006; Eeva et al., 2007).

2. The CD40-mediated upregulation of anti-apoptotic proteins delay the onset of the Fas-induced cell death. Both Flip short and long forms were upregulated in 4-24 h after CD40 stimulation and decrease thereafter reaching their lowest levels after $72 \mathrm{~h}$ (Hennino et al., 2000; Eeva et al., 2007). NFKB activation played crucial role on FLIP overexpression since its inhibition blocked the CD40-induced Flip overexpression (Hennino et al., 2000; Eeva et al., 2007). Results from different human cell lines showed that anti-apoptotic members of Bcl-2 family, Bfl-1/A1, and Bcl-xl, were upregulated by CD40. RNA of $\mathrm{Bcl}-\mathrm{xl}$ and Bfl- 1 are induced in $4-8 \mathrm{~h}$ following CD40 stimulation. The transcriptions of these anti-apoptotic proteins upon CD40 activation were completely abolished in the presence of constitutive IkB mutant, where exogenous $\mathrm{Bcl}-\mathrm{xl}$ could restore the resistance to Fas-mediated cell death (Lee et al., 1999).

In the presence of CD40L different B cell lines and primary splenocytes upregulated Gadd $45 \beta$ expression in an hour, much earlier than the observable increase in the expressions of $\mathrm{Bcl}-\mathrm{xl}$ and Flip. Overexpression of this protein, in the level comparable with normal cells upon CD40 activation (Zazzeroni et al., 2003), led to Fas resistance. Gadd $45 \beta$ inhibited the caspase activation and 
the mitochondrion depolarization, but neither the DISC formation, nor the early times Bid cleavage. These result suggest that Gadd $45 \beta$ inhibited the caspase activation following the activation of mitochondrial pathway (Zazzeroni et al., 2003).

\section{ADHESION, CELL-CELL CONTACT}

$\mathrm{B}$ cell contact either with $\mathrm{T}$ cells or with follicular dendritic cells influences Fas-induced cell death. In the case of antigen-specific $\mathrm{T}$ and $\mathrm{B}$ cell interaction, upon the formation of a $\mathrm{T}$ cell-B cell connection mediated by MHCII and the specific TCR, adhesion molecules reinforce $\mathrm{T}$ cell-B cell linkage, keeping the two cells in contact. Inhibition of the most prominent adhesion molecule pair, LFA1-ICAM1 by anti-LFA1 or an anti-ICAM1, completely blocked the cell death of target B cells (Wang and Lenardo, 1997) while the anti-CD2, anti-CD48 antibodies have weaker but significant effects. Because none of these antibodies directly affected anti-Fasmediated lysis, the critical importance of the cell-cell contact time between the FasL-expressing T cells and Fas-positive target cells is suggested (Wang and Lenardo, 1997). Thus antigen-specific T cells fail to lyse B cells in the absence of long-term Fas-FasL signaling (Wang and Lenardo, 1997).

\section{B7.2}

The expression of the prominent co-stimulatory molecule B7.2 is repressed in anergic B cells (Ho et al., 1994; Lenschow et al., 1994). In B7.2 transgenic mice, where the expression level of B7.2 in anergic B cells was restored and thus comparable with the level that is normally present on antigen-sensitive responding B cells, T cells did not kill the anergic B cells with appropriate antigen specificity (Rathmell et al., 1998). However, in vitro, B7.2 transgenic and normal anergic B cells were equally sensitive to antiFas-induced cell death. The survival effect of the co-stimulatory molecule was mediated by upregulated IL-4 production, which was only detectable upon the cooperation of antigen-specific $\mathrm{T}$ cells and B cells with high B7.2 expression and not in the case of B7.2 non-expressing B cells (Rathmell et al., 1998). In contrast, others found that blocking antibodies to B7.1 and B7.2 had no effect on CD4 T cell-induced cell death of normal, non-anergic B cells (Wang and Lenardo, 1997).

\section{FDC}

GC B cells undergo apoptosis at least partially in a caspasedependent manner when detached from their microenvironment (Lindhout et al., 1995). This process does not require any inducing death receptor signal, but Fas signaling accelerates this cell death route (van Eijk et al., 2001b). FasL-independent organization of preformed DISC and constant association of FADD, caspase-8, and FLIP $_{\mathrm{L}}$ with Fas were found in freshly isolated GC B cells. Accordingly, caspase- 8 activation was observed within $40 \mathrm{~min}$ of the detachment of GC B cells without the need of Fas ligation (Hennino et al., 2001).

In the presence of FDC, GC B cells are protected from apoptosis, even after Fas activation both in mouse (Schwarz et al., 1999) and human systems (Lindhout et al., 1995; Koopman et al., 1997; van Eijk et al., 2001a), regardless of the fact that the presence of FDC enhances Fas expression in B cells (Tsunoda et al., 2000) and that FDC in the germinal center express FasL (Verbeke et al., 1999).
How the coculture with FDC is capable of inhibiting anti-Fasgenerated cell death in B cells is not fully understood, but FLIP seems to be the crucial actor in this process (Schwarz et al., 1999).

\section{IL-4}

Beside direct cell-cell contact, B cell survival is regulated by interleukins. Addition of IL-4 to CD40L-stimulated B cells reduces Fas-induced apoptosis (Foote et al., 1996a, 1998; Koizumi et al., 1996; Nakanishi et al., 1996; Wurster et al., 2002). The IL-4generated resistance was synergistic with CD40L mediated survival (Nakanishi et al., 1996). Using suboptimal doses of anti-IgM, IL-4 was found to be strongly synergistic with BCR-transduced rescue signals (Foote et al., 1996a). However, the signaling mechanism utilized by IL- 4 for Fas resistance differed from that used by IgM: first, the time required for IL-4-induced survival signal was longer than the one mediated by BCR (12-24 h); second, the IL-4 driven pathway whereas PKC independent (Foote et al., 1996a) absolutely required STAT6; third, through STAT6 activation IL-4 directly upregulated the Bcl-xl level (Wurster et al., 2002). One can note that some authors detected only marginal IL-4-induced upregulation of Bcl-xl (Schneider et al., 1997).

Unfortunately the CD40-independent survival potential of IL-4 signaling has not been yet investigated. From this study, the effect of overproduced Bcl-xl cannot be dissociated from the elevated FLIP level due to CD40 signaling. Upon upregulation of FLIP by BCR or CD40 signaling, Bcl-xl can clearly inhibit the Fas-mediated cell death pathway. However, the question remains as to whether the IL-4-induced upregulation of $\mathrm{Bcl}-\mathrm{xl}$ alone is able to reduce Fas-induced cell death in B cells. Nonetheless, the most important consequence of this effect is that IL-4 transduced survival signaling, as non-antigen-specific signaling was not impaired in tolerant $B$ cells while the BCR-induced survival signal did not function in these cells (Foote et al., 1998). The IL-4 signaling, by inhibiting the mitochondrial pathway, is able to keep the anergic $\mathrm{B}$ cells alive.

\section{CpG}

Hypomethylated bacterial DNA contains a high percentage of CpG motifs that activate $95 \%$ of resting B cells. CpG containing oligonucleotides were found to effectively protect CD40Lstimulated B cells from CD4+ T cell-mediated apoptosis but had no effect on IgM-induced resistance (Wang and Lenardo, 1997). The CpG-triggered signaling pathways have not been extensively characterized (Table 2). Coligation of TLR9 and BCR promotes auto-antigen-specific B cell responses (Chaturvedi et al., 2008). This signaling pathway can break BCR tolerance and thereby rescue autoreactive but anergic B cells from Fas-mediated apoptosis.

\section{FURTHER QUESTIONS}

Our knowledge about the role of Fas in T-independent B cell responses is very limited. In the absence of $\mathrm{T}$ cell-B cell interaction, the potential for Fas-FasL interaction remains unknown. However the control of activated B cells is also crucial in this type of response. The B1 cell population has been suggested as FasL targets (see Table 1), but the source of FasL is still unknown.

As long-term $\mathrm{T}$ cell-B cell interaction requires common antigen-specificity, self-reactive $B$ cells are probably not killed by $\mathrm{T}$ 
cells specific for external antigen. The role of Treg cells would be a very interesting aspect of MHCII-Fas interaction. Treg cells are key actors of peripheral tolerance to self-antigen. The expression and function of FasL was established in this immunosuppressive cell population (Baatar et al., 2007). Treg cells may eliminate autoreactive $\mathrm{B}$ cells through prolonged FasL-Fas triggering due to direct MHCII-TCR interaction (Janssens et al., 2003). Otherwise, in the absence of prolonged self-reactive $B$ cell-T cell interactions, the killing of self-recognizing $B$ cells, and the elevated number of autoimmune B cells in lpr mice would not be explained.

Fas aggregation, raft localization, and cytoskeleton association may be the targets of a survival pathway but little has been published about the BCR-mediated, protein-synthesis-independent, regulation of Fas signaling. Some authors have reported that BCRmediated survival was absolutely dependent on protein synthesis (Foote et al., 1996b; Schneider et al., 1997) while others using the A20 cell line found that this effect was almost fully incomplete (Catlett and Bishop, 1999; Hinshaw et al., 2003). Based on Bras

\section{REFERENCES}

Ait-Azzouzene, D., Kono, D. H., Gonzalez-Quintial, R., McHeyzerWilliams, L. J., Lim, M., Wickramarachchi, D., Gerdes, T., Gavin, A. L., Skog, P., McHeyzer-Williams, M. G., Nemazee, D., and Theofilopoulos, A. N. (2010). Deletion of IgG-switched autoreactive B cells and defects in Fas(lpr) lupus mice. J. Immunol. 185, 1015-1027.

Alam, M. K., Davison, S., Siddiqui, N., Norton, J. D., and Murphy, J. J. (1997). Ectopic expression of Bcl-2, but not Bcl-xL rescues Ramos B cells from Fas-mediated apoptosis. Eur. J. Immunol. 27, 3485-3491.

Al-Daccak, R., Mooney, N., and Charron, D. (2004). MHC class II signaling in antigen-presenting cells. Curr. Opin. Immunol. 16, 108-113.

Baatar, D., Olkhanud, P., Sumitomo, K., Taub, D., Gress, R., and Biragyn, A. (2007). Human peripheral blood T regulatory cells (Tregs), functionally primed CCR4+ Tregs and unprimed CCR4- Tregs, regulate effector $\mathrm{T}$ cells using FasL. J. Immunol. 178, 4891-4900.

Barrington, R. A., Zhang, M., Zhong, X., Jonsson, H., Holodick, N., Cherukuri, A., Pierce, S. K., Rothstein, T. L., and Carroll, M. C. (2005). CD21/CD19 coreceptor signaling promotes B cell survival during primary immune responses. J. Immunol. 175, 2859-2867.

Beisner, D. R., Ch'en, I. L., Kolla, R. V., Hoffmann, A., and Hedrick, S. M. (2005). Cutting edge: innate immunity conferred by $\mathrm{B}$ cells is regulated by caspase-8. J. Immunol. 175, 3469-3473.
Benson, R. J., Hostager, B. S., and Bishop, G. A. (2006). Rapid CD40-mediated rescue from CD95-induced apoptosis requires TNFR-associated factor- 6 and PI3K. Eur. J. Immunol. 36, 2535-2543.

Bishop, G. A., and Hostager, B. S. (2003). The CD40-CD154 interaction in B cell-T cell liaisons. Cytokine Growth Factor Rev. 14, 297-309.

Blancheteau, V., Charron, D., and Mooney, N. (2002). HLA class II signals sensitize $\mathrm{B}$ lymphocytes to apoptosis via Fas/CD95 by increasing FADD recruitment to activated Fas and activation of caspases. Hum. Immunol. 63, 375-383.

Bras, A., Martinez, A. C., and Baixeras, E. (1997). B cell receptor crosslinking prevents Fas-induced cell death by inactivating the IL-1 betaconverting enzyme protease and regulating $\mathrm{Bcl}-2 / \mathrm{Bcl}-\mathrm{x}$ expression. J. Immunol. 159, 3168-3177.

Carey, G. B., Donjerkovic, D., Mueller, C. M., Liu, S., Hinshaw, J. A., Tonnetti, L., Davidson, W., and Scott, D. W. (2000). B-cell receptor and Fasmediated signals for life and death. Immunol. Rev. 176, 105-115.

Carter, R. H., and Fearon, D. T. (1992). CD19: lowering the threshold for antigen receptor stimulation of $\mathrm{B}$ lymphocytes. Science 256, 105-107.

Catlett, I. M., and Bishop, G. A. (1999). Cutting edge: a novel mechanism for rescue of B cells from CD95/Fasmediated apoptosis. J. Immunol. 163, 2378-2381.

Catlett, I. M., Xie, P., Hostager, B. S., and Bishop, G. A. (2001). Signaling through MHC class II molecules blocks CD95-induced apoptosis. J. Immunol. 166, 6019-6024.

theory (Bras et al., 1997) two independent, but additive pathways, a prompt PKC-regulated and a time dependent NFkB directed, protein-synthesis-dependent pathway may collaborate in BCRmediated survival. PKC could inhibit the very early, necessary step of Fas activation. Receptor aggregation (in Jurkat cells; Ruiz-Ruiz et al., 1999) and PKC $\zeta$ was mentioned as a component of the DISC with inhibitory capacity (Leroy et al., 2005). A similar mechanism is supposed for B cells, explaining the reduced DISC formation upon BCR-induced PKC activation.

\section{ACKNOWLEDGMENTS}

We thank Krittalak Chakrabandhu for critical reading of the manuscript. The work was supported by Hungarian-French Intergovernmental S\&T cooperation programme, the ETT 392, OTKA 60760, and by grants from the Ligue Nnationale contre Le Cancer (LNCC), the Association pour la Recherche contre le Cancer (ARC), the Agence Nationale de la Recherche (ANR), and the Institute National du Cancer (INCa).

Chaturvedi, A., Dorward, D., and Pierce, S. K. (2008). The B cell receptor governs the subcellular location of Toll-like receptor 9 leading to hyperresponses to DNA-containing antigens. Immunity 28, 799-809.

Choe, J., Kim, H. S., Zhang, X. Armitage, R. J., and Choi, Y. S (1996). Cellular and molecular factors that regulate the differentiation and apoptosis of germinal center B cells. Anti-Ig down-regulates Fas expression of CD40 ligandstimulated germinal center B cells and inhibits Fas-mediated apoptosis. J. Immunol. 157, 1006-1016.

Chu, J. L., Ramos, P., Rosendorff, A., Nikolic-Zugic, J., Lacy, E., Matsuzawa, A., and Elkon, K. B. (1995). Massive upregulation of the Fas ligand in lpr and gld mice: implications for Fas regulation and the graftversus-host disease-like wasting syndrome. J. Exp. Med. 181, 393-398.

Cleary, A. M., Fortune, S. M., Yellin, M. J., Chess, L., and Lederman, S. (1995). Opposing roles of CD95 (Fas/APO-1) and CD40 in the death and rescue of human low density tonsillar B cells. J. Immunol. 155, 3329-3337.

Coffey, F., and Manser, T. (2010). Expression of cellular FLIP by B cells is required for their participation in an immune response. J. Immunol. 184, 4871-4879.

Cohen, P. L., and Eisenberg, R. A (1991). Lpr and gld: single gene models of systemic autoimmunity and lymphoproliferative disease. Annu. Rev. Immunol. 9, 243-269.

Daniel, P. T., and Krammer, P. H. (1994). Activation induces sensitivity toward APO-1 (CD95)-mediated apoptosis in human B cells. $J$. Immunol. 152, 5624-5632.

Eeva, J., Ropponen, A., Nuutinen, U., Eeva, S. T., Matto, M., Eray, M., and Pelkonen, J. (2007). The CD40induced protection against CD95mediated apoptosis is associated with a rapid upregulation of antiapoptotic c-FLIP. Mol. Immunol. 44, 1230-1237.

Elmore, S. (2007). Apoptosis: a review of programmed cell death. Toxicol. Pathol. 35, 495-516.

Fisher, G. H., Rosenberg, F. J., Straus, S. E., Dale, J. K., Middleton, L. A., Lin A. Y., Strober, W., Lenardo, M. J., and Puck, J. M. (1995). Dominant interfering Fas gene mutations impair apoptosis in a human autoimmune lymphoproliferative syndrome. Cell 81, 935-946.

Foote, L. C., Howard, R. G., MarshakRothstein, A., and Rothstein, T. L. (1996a). IL-4 induces Fas resistance in B cells. J. Immunol. 157, 2749-2753.

Foote, L. C., Schneider, T. J., Fischer G. M., Wang, J. K., Rasmussen, B., Campbell, K. A., Lynch, D. H., Ju, S. T., Marshak-Rothstein, A., and Rothstein, T. L. (1996b). Intracellular signaling for inducible antigen receptor-mediated Fas resistance in B cells. J. Immunol. 157, 1878-1885.

Foote, L. C., Marshak-Rothstein, A., and Rothstein, T. L. (1998). Tolerant B lymphocytes acquire resistance to Fas-mediated apoptosis after treatment with interleukin 4 but not after treatment with specific antigen unless a surface immunoglobulin threshold is exceeded. J. Exp. Med. 187, 847-853. 
Garrone, P., Neidhardt, E. M., Garcia, E., Galibert, L., van Kooten, C., and Banchereau, J. (1995). Fas ligation induces apoptosis of CD40activated human B lymphocytes. $J$. Exp. Med. 182, 1265-1273.

Goodnow, C. C. (1996). Balancing immunity and tolerance: deleting and tuning lymphocyte repertoires. Proc. Natl. Acad. Sci. U.S.A. 93, 2264-2271.

Grammer,A. C., Bergman, M.C., Miura, Y., Fujita, K., Davis, L. S., and Lipsky, P. E. (1995). The CD40 ligand expressed by human B cells costimulates B cell responses. J. Immunol. 154, 4996-5010.

Grammer, A. C., McFarland, R. D., Heaney, J., Darnell, B. F., and Lipsky, P. E. (1999). Expression, regulation, and function of $\mathrm{B}$ cellexpressed CD154 in germinal centers. J. Immunol. 163, 4150-4159.

Guzman-Rojas, L., Sims-Mourtada, J. C., Rangel, R., and Martinez-Valdez, H. (2002). Life and death within germinal centres: a double-edged sword. Immunology 107, 167-175.

Han, J., Zhong, C. Q., and Zhang, D. W. (2012). Programmed necrosis: backup to and competitor with apoptosis in the immune system. Nat. Immunol. 12, 1143-1149.

Hancz, A., Koncz, G., Szili, D., and Sarmay, G. (2012). TLR9-mediated signals rescue B-cells from Fas-induced apoptosis via inactivation of caspases. Immunol. Lett. 143, 77-84.

Hao, Z., Duncan, G. S., Seagal, J., Su, Y. W., Hong, C., Haight, J., Chen, N. J., Elia, A., Wakeham, A., Li, W. Y., Liepa, J., Wood, G. A., Casola, S., Rajewsky, K., and Mak, T. W. (2008). Fas receptor expression in germinal-center $\mathrm{B}$ cells is essential for $\mathrm{T}$ and $\mathrm{B}$ lymphocyte homeostasis. Immunity 29 , 615-627.

Hao, Z., Hampel, B., Yagita, H., and Rajewsky, K. (2004). T cell-specific ablation of Fas leads to Fas ligandmediated lymphocyte depletion and inflammatory pulmonary fibrosis. $J$. Exp. Med. 199, 1355-1365.

Hennino, A., Berard, M., CasamayorPalleja, M., Krammer, P. H., and Defrance, T. (2000). Regulation of the Fas death pathway by FLICE-inhibitory protein in primary human B cells. J. Immunol. 165, 3023-3030.

Hennino, A., Berard, M., Krammer, P. H., and Defrance, T. (2001). FLICEinhibitory protein is a key regulator of germinal center B cell apoptosis. J. Exp. Med. 193, 447-458.

Hinshaw, J. A., Mueller, C. M., Scott, D. W., and Williams, M. S. (2003). $\mathrm{B}$ cell receptor signaling mediates immediate protection from Fasinduced apoptosis upstream of caspase activation through an atypical protein kinase $\mathrm{C}$ isozyme and de novo protein synthesis. Eur. J. Immunol. 33, 2490-2500.

Hirose, S., Yan, K., Abe, M., Jiang, Y., Hamano, Y., Tsurui, H., and Shirai, T. (1997). Precursor B cells for autoantibody production in genomically Fas-intact autoimmune disease are not subject to Fas-mediated immune elimination. Proc. Natl. Acad. Sci. U.S.A. 94, 9291-9295.

Ho, L., Davis, R. E., Conne, B., Chappuis, R., Berczy, M., Mhawech, P., Staudt, L. M., and Schwaller, J. (2005). MALT1 and the API2-MALT1 fusion act between CD40 and IKK and confer NF-kappa B-dependent proliferative advantage and resistance against FAS-induced cell death in B cells. Blood 105, 2891-2899.

Ho, W. Y., Cooke, M. P., Goodnow, C. C., and Davis, M. M. (1994). Resting and anergic $B$ cells are defective in CD28-dependent costimulation of naive CD4+ T cells. J. Exp. Med. 179, 1539-1549.

Huck, S., Jamin, C., Youinou, P., and Zouali, M. (1998). High-density expression of CD95 on B cells and underrepresentation of the B-1 cell subset in human lupus. J. Autoimmun. 11, 449-455.

Huo, J., Xu, S., Guo, K., Zeng, Q., and Lam, K. P. (2009). Genetic deletion of faim reveals its role in modulating c-FLIP expression during CD95mediated apoptosis of lymphocytes and hepatocytes. Cell Death Differ. 16, 1062-1070.

Imtiyaz, H. Z., Rosenberg, S., Zhang, Y., Rahman, Z. S., Hou, Y. J., Manser, T., and Zhang, J. (2006). The Fasassociated death domain protein is required in apoptosis and TLRinduced proliferative responses in $\mathrm{B}$ cells. J. Immunol. 176, 6852-6861.

Jacobson, B. A., Panka, D. J., Nguyen, K. A., Erikson, J., Abbas, A. K., and Marshak-Rothstein, A. (1995). Anatomy of autoantibody production: dominant localization of antibody-producing cells to $\mathrm{T}$ cell zones in Fas-deficient mice. Immunity 3, 509-519.

Janssens, W., Carlier, V., Wu, B., VanderElst, L., Jacquemin, M. G., and Saint-Remy, J. M. (2003). $\mathrm{CD} 4+\mathrm{CD} 25+\mathrm{T}$ cells lyse antigenpresenting $\mathrm{B}$ cells by Fas-Fas ligand interaction in an epitopespecific manner. J. Immunol. 171, 4604-4612.

Kabra, N. H., Cado, D., and Winoto, A. (1999). A tailless fas-FADD deatheffector domain chimera is sufficient to execute Fas function in $\mathrm{T}$ cells but not B cells of MRL-lpr/lpr mice. J. Immunol. 162, 2766-2774.

Kater, A. P., Dicker, F., Mangiola, M., Welsh, K., Houghten, R., Ostresh, J., Nefzi, A., Reed, J. C., Pinilla, C., and Kipps, T. J. (2005). Inhibitors of XIAP sensitize CD40-activated chronic lymphocytic leukemia cells to CD95-mediated apoptosis. Blood 106, 1742-1748.

Khaled, A. R., and Durum, S. K. (2003). Death and Baxes: mechanisms of lymphotrophic cytokines. Immunol. Rev. 193, 48-57.

Khan, W. N. (2009). B cell receptor and BAFF receptor signaling regulation of B cell homeostasis. J. Immunol. 183, 3561-3567.

Kischkel, F. C., Hellbardt, S., Behrmann, I., Germer, M., Pawlita, M., Krammer, P. H., Peter, M. E. (1995). Cytotoxicity-dependent APO-1 (Fas/CD95)-associated proteins form a death-inducing signaling complex (DISC) with the receptor. EMBO J.14, 5579-5588.

Kodama, S., Suzuki, M., Arita, M., and Mogi, G. (2001). Increase in tonsillar germinal centre B-1 cell numbers in IgA nephropathy (IgAN) patients and reduced susceptibility to Fas-mediated apoptosis. Clin. Exp. Immunol. 123, 301-308.

Koizumi, T., Wang, J., Suzuki, Y., Masuda, K., and Watanabe, T. (1996). Regulation of bcl-xL expression and Fas susceptibility in mouse B cells by $\mathrm{CD} 40$ ligation, surface IgM crosslinking and IL-4. Mol Immunol. 33, 1247-1253.

Komano, H., Ikegami, Y., Yokoyama, M., Suzuki, R., Yonehara, S., Yamasaki, Y., and Shinohara, N. (1999). Severe impairment of B cell function in lpr/lpr mice expressing transgenic Fas selectively on B cells. Int Immunol. 11, 1035-1042.

Koopman, G., Keehnen, R. M., Lindhout, E., Zhou, D. F., de Groot, C. and Pals, S. T. (1997). Germinal center B cells rescued from apoptosis by CD40 ligation or attachment to follicular dendritic cells, but not by engagement of surface immunoglobulin or adhesion receptors, become resistant to CD95induced apoptosis. Eur. J. Immunol. $27,1-7$.

Lagresle, C., Bella, C., Daniel, P. T., Krammer, P. H., and Defrance, $T$. (1995). Regulation of germinal center B cell differentiation. Role of the human APO-1/Fas (CD95) molecule. J. Immunol. 154, 5746-5756.

Lagresle, C., Mondiere, P., Bella, C., Krammer, P. H., and Defrance, T. (1996). Concurrent engagement of CD40 and the antigen receptor protects naive and memory human B cells from APO-1/Fasmediated apoptosis. J. Exp. Med. 183 , 1377-1388

Lanvin, O., Guglielmi, P., Fuentes, V., Gouilleux-Gruart, V., Maziere, C., Bissac, E., Regnier, A., Benlagha, K., Gouilleux, F., and Lassoued, K. (2003). TGF-betal modulates Fas (APO-1/CD95)-mediated apoptosis of human pre-B cell lines. Eur. J. Immunol. 33, 1372-1381.

Lee, H. H., Dadgostar, H., Cheng, Q., Shu, J., and Cheng, G. (1999). NF-kappaB-mediated up-regulation of $\mathrm{Bcl}-\mathrm{x}$ and $\mathrm{Bfl}-1 / \mathrm{Al}$ is required for CD40 survival signaling in $\mathrm{B}$ lymphocytes. Proc. Natl. Acad. Sci. U.S.A. 96, 9136-9141.

Leithauser, F., Dhein, J., Mechtersheimer, G., Koretz, K., Bruderlein, S., Henne, C., Schmidt, A., Debatin, K. M., Krammer, P. H., and Moller, P. (1993). Constitutive and induced expression of APO-1, a new member of the nerve growth factor/tumor necrosis factor receptor superfamily, in normal and neoplastic cells. Lab. Invest. 69, 415-429.

Lenardo, M. J., Oliveira, J. B., Zheng, L., and Rao, V. K. (2010). ALPSten lessons from an international workshop on a genetic disease of apoptosis. Immunity 32, 291-295.

Lenschow, D. J., Sperling, A. I., Cooke, M. P., Freeman, G., Rhee, L., Decker, D. C., Gray, G., Nadler, L. M., Goodnow, C. C., and Bluestone, J. A. (1994). Differential up-regulation of the B7-1 and B7-2 costimulatory molecules after Ig receptor engagement by antigen. J. Immunol. 153, 1990-1997.

Leroy, I., de Thonel, A., Laurent, G., and Quillet-Mary, A. (2005). Protein kinase $\mathrm{C}$ zeta associates with death inducing signaling complex and regulates Fas ligandinduced apoptosis. Cell. Signal. 17, 1149-1157.

Lindhout, E., Lakeman, A., and de Groot, C. (1995). Follicular dendritic cells inhibit apoptosis in human B lymphocytes by a rapid and irreversible blockade of preexisting endonuclease. J. Exp. Med. 181, 1985-1995.

Liu, Y. J., Barthelemy, C., de Bouteiller, O., Arpin, C., Durand, I., and Banchereau, J. (1995). Memory B cells from human tonsils colonize mucosal epithelium and directly present antigen to $\mathrm{T}$ cells by rapid up-regulation of B7-1 and B7-2. Immunity 2, 239-248.

Liu, Y. J., de Bouteiller, O., and FugierVivier, I. (1997). Mechanisms of 
selection and differentiation in germinal centers. Curr. Opin. Immunol. 9, 256-262.

Mandik, L., Nguyen, K. A., and Erikson, J. (1995). Fas receptor expression on B-lineage cells. Eur. J. Immunol. 25, 3148-3154.

Masuda, K., Wang, J., and Watanabe, T. (1997). Reduced susceptibility to Fas-mediated apoptosis in B-1 cells. Eur. J. Immunol. 27, 449-455

Merville, P., Dechanet, J., Desmouliere, A., Durand, I., de Bouteiller, O., Garrone, P., Banchereau, J., and Liu, Y. J. (1996). Bcl-2+ tonsillar plasma cells are rescued from apoptosis by bone marrow fibroblasts. J. Exp. Med. 183, 227-236.

Miyawaki, T., Uehara, T., Nibu, R., Tsuji, T., Yachie, A., Yonehara, S., and Taniguchi, N. (1992). Differential expression of apoptosis-related Fas antigen on lymphocyte subpopulations in human peripheral blood. J. Immunol. 149, 3753-3758.

Mizuno, T., Zhong, X., and Rothstein, T. L. (2003). Fas-induced apoptosis in B cells. Apoptosis 8, 451-460.

Moller, P., Henne, C., Leithauser, F., Eichelmann, A., Schmidt, A., Bruderlein, S., Dhein, J., and Krammer, P. H. (1993). Coregulation of the APO1 antigen with intercellular adhesion molecule-1 (CD54) in tonsillar $B$ cells and coordinate expression in follicular center B cells and in follicle center and mediastinal B-cell lymphomas. Blood 81, 2067-2075.

Mongini, P. K., Jackson, A. E., Tolani, S., Fattah, R. J., and Inman, J. K. (2003). Role of complementbinding CD21/CD19/CD81 in enhancing human $\mathrm{B}$ cell protection from Fas-mediated apoptosis. J. Immunol. 171, 5244-5254.

Moriyama, H., and Yonehara, S. (2007). Rapid up-regulation of cFLIP expression by BCR signaling through the PI3K/Akt pathway inhibits simultaneously induced Fas-mediated apoptosis in murine B lymphocytes. Immunol. Lett. 109, 36-46.

Nakanishi, K., Matsui, K., Kashiwamura, S., Nishioka, Y., Nomura, J., Nishimura, Y., Sakaguchi, N., Yonehara, S., Higashino, K., and Shinka, S. (1996). IL-4 and anti-CD40 protect against Fas-mediated B cell apoptosis and induce B cell growth and differentiation. Int. Immunol. 8, 791-798.

Nilsson, N., Ingvarsson, S., and Borrebaeck, C. A. (2000). Immature B cells in bone marrow express Fas/FasL. Scand. J. Immunol. 51, 279-284.

Nishiuchi, R., Yoshino, T., Matsuo, Y., Sakuma, I., Cao, L., Seino, Y.,
Takahashi, K., and Akagi, T. (1996). The Fas antigen is detected on immature B cells and the representative cell lines show Fasmediated apoptosis. Br. J. Haematol. 92, 302-307.

Oberst, A., Dillon, C. P., Weinlich, R., McCormick, L. L., Fitzgerald, P., Pop, C., Hakem, R., Salvesen, G. S., and Green, D. R. (2011). Catalytic activity of the caspase-8-FLIP(L) complex inhibits RIPK3-dependent necrosis. Nature 471, 363-367.

Onel, K. B., Tucek-Szabo, C. L., Ashany, D., Lacy, E., Nikolic-Zugic, J., and Elkon, K. B. (1995). Expression and function of the murine CD95/FasR/APO-1 receptor in relation to B cell ontogeny. Eur. J. Immunol. 25, 2940-2947.

Opferman, J. T. (2008). Apoptosis in the development of the immune system. Cell Death Differ. 15, 234-242.

Owyang, A. M., Tumang, J. R., Schram, B. R., Hsia, C. Y., Behrens, T. W., Rothstein, T. L., and Liou, H. C. (2001). c-Rel is required for the protection of B cells from antigen receptor-mediated, but not Fasmediated, apoptosis. J. Immunol. 167, 4948-4956.

Qian, Y., Conway, K. L., Lu, X., Seitz, H. M., Matsushima, G. K., and Clarke, S. H. (2006). Autoreactive MZ and B-1 B-cell activation by Faslpr is coincident with an increased frequency of apoptotic lymphocytes and a defect in macrophage clearance. Blood 108, 974-982.

Rathmell, J. C., Cooke, M. P., Ho, W. Y., Grein, J., Townsend, S. E., Davis, M. M., and Goodnow, C. C. (1995). CD95 (Fas)-dependent elimination of self-reactive B cells upon interaction with CD4+ T cells. Nature 376, 181-184.

Rathmell, J. C., Fournier, S., Weintraub, B. C., Allison, J. P., and Goodnow, C. C. (1998). Repression of B7.2 on self-reactive B cells is essential to prevent proliferation and allow Fas-mediated deletion by CD4(+) T cells. J. Exp. Med. 188, 651-659.

Rathmell, J. C., and Goodnow, C. C. (1995). Autoimmunity. The Fas track. Curr. Biol. 5, 1218-1221.

Rathmell, J. C., Townsend, S. E., Xu, J. C., Flavell, R. A., and Goodnow, C. C. (1996). Expansion or elimination of $B$ cells in vivo: dual roles for CD40and Fas (CD95)-ligands modulated by the $\mathrm{B}$ cell antigen receptor. Cell 87, 319-329.

Rieux-Laucat, F., Le Deist, F., Hivroz, C., Roberts, I. A., Debatin, K. M., Fischer, A., and de Villartay, J. P. (1995). Mutations in Fas associated with human lymphoproliferative syndrome and autoimmunity. Science 268, 1347-1349.

Rothstein, T. L. (2000). Inducible resistance to Fas-mediated apoptosis in B cells. Cell Res. 10, 245-266.

Rothstein, T. L., Wang, J. K., Panka, D. J., Foote, L. C., Wang, Z., Stanger, B., Cui, H., Ju, S. T., and Marshak-Rothstein, A. (1995). Protection against Fas-dependent Th1-mediated apoptosis by antigen receptor engagement in B cells. Nature 374, 163-165.

Ruiz-Ruiz, C., Robledo, G., Font, J. Izquierdo, M., and Lopez-Rivas, A. (1999). Protein kinase C inhibits CD95 (Fas/APO-1)-mediated apoptosis by at least two different mechanisms in Jurkat T cells. J. Immunol. 163, 4737-4746.

Sampalo, A., Navas, G., Medina, F., Segundo, C., Camara, C., and Brieva, J. A. (2000). Chronic lymphocytic leukemia B cells inhibit spontaneous Ig production by autologous bone marrow cells: role of CD95-CD95L interaction. Blood 96, 3168-3174.

Scaffidi, C., Schmitz, I., Krammer, P. H., Peter, M. E. (1999). The role of c-FLIP in modulation of CD95induced apoptosis. J. Biol. Chem. 274, 1541-1548.

Schattner, E. J., Elkon, K. B., Yoo, D. H. Tumang, J., Krammer, P. H., Crow, M. K., and Friedman, S. M. (1995). CD40 ligation induces Apo-1/Fas expression on human $\mathrm{B}$ lymphocytes and facilitates apoptosis through the Apo-1/Fas pathway. J. Exp. Med. 182 , 1557-1565.

Schneider, T. J., Fischer, G. M., Donohoe, T. J., Colarusso, T. P., and Rothstein, T. L. (1999). A novel gene coding for a Fas apoptosis inhibitory molecule (FAIM) isolated from inducibly Fas-resistant B lymphocytes. J. Exp. Med. 189, 949-956.

Schneider, T. J., Grillot, D., Foote, L. C., Nunez, G. E., and Rothstein, T. L. (1997). Bcl-x protects primary B cells against Fas-mediated apoptosis. J. Immunol. 159, 4834-4839.

Scholl, P. R., and Geha, R. S. (1994) MHC class II signaling in B-cell activation. Immunol. Today 15, 418-422.

Schram, B. R., and Rothstein, T. L. (2003). NF-kappa B is required for surface Ig-induced Fas resistance in B cells. J. Immunol. 170, 3118-3124.

Schwarz, Y. X., Yang, M., Qin, D., Wu, J., Jarvis, W. D., Grant, S., Burton, G. F., Szakal, A. K., and Tew, J. G. (1999). Follicular dendritic cells protect malignant B cells from apoptosis induced by anti-Fas and antineoplastic agents. J. Immunol. 163, 6442-6447.
Shima, Y., Nishimoto, N., Ogata, A., Fujii, Y., Yoshizaki, K., and Kishimoto, T. (1995). Myeloma cells express Fas antigen/APO-1 (CD95) but only some are sensitive to antiFas antibody resulting in apoptosis. Blood 85, 757-764.

Shlomchik, M. J., Madaio, M. P., Ni, D., Trounstein, M., and Huszar, D. (1994). The role of B cells in lpr/lprinduced autoimmunity. J. Exp. Med. 180, 1295-1306.

Smith, K. G., Nossal, G. J., and Tarlinton, D. M. (1995). FAS is highly expressed in the germinal center but is not required for regulation of the B-cell response to antigen. Proc. Natl. Acad. Sci. U.S.A. 92, 11628-11632.

Stranges, P. B., Watson, J., Cooper, C. J., Choisy-Rossi, C. M., Stonebraker, A. C., Beighton, R. A., Hartig, H., Sundberg, J. P., Servick, S., Kaufmann, G., Fink, P. J., and Chervonsky, A. V. (2007). Elimination of antigenpresenting cells and autoreactive $\mathrm{T}$ cells by Fas contributes to prevention of autoimmunity. Immunity 26 , 629-641.

Suzuki, H., Matsuda, S., Terauchi, Y., Fujiwara, M., Ohteki, T., Asano, T., Behrens, T. W., Kouro, T., Takatsu, K., Kadowaki, T., and Koyasu, S. (2003). PI3K and Btk differentially regulate $\mathrm{B}$ cell antigen receptor-mediated signal transduction. Nat. Immunol. 4, 280-286.

Takahashi, T., Tanaka, M., Brannan, C. I., Jenkins, N. A., Copeland, N. G., Suda, T., and Nagata, S. (1994). Generalized lymphoproliferative disease in mice, caused by a point mutation in the Fas ligand. Cell 76, 969-976.

Takahashi, Y., Ohta, H., and Takemori, T. (2001). Fas is required for clonal selection in germinal centers and the subsequent establishment of the memory B cell repertoire. Immunity 14, 181-192.

Truman, J. P., Choqueux, C., Tschopp, J., Vedrenne, J., Le Deist, F., Charron, D., and Mooney, N. (1997). HLA class II-mediated death is induced via Fas/Fas ligand interactions in human splenic B lymphocytes. Blood 89, 1996-2007.

Tsunoda, R., Heinen, E., and Sugai, N. (2000). Follicular dendritic cells in vitro modulate the expression of Fas and Bcl-2 on germinal center B cells. Cell Tissue Res. 299, 395-402.

Tumang, J. R., Negm, R. S., Solt, L. A., Schneider, T. J., Colarusso, T. P., Hastings, W. D., Woodland, R. T., and Rothstein, T. L. (2002). BCR engagement induces Fas resistance in primary B cells in the absence of functional Bruton's tyrosine kinase. J. Immunol. 168, 2712-2719. 
van Eijk, M., Defrance, T., Hennino, A., and de Groot, C. (2001a). Death-receptor contribution to the germinal-center reaction. Trends Immunol. 22, 677-682.

van Eijk, M., Medema, J. P., and de Groot, C. (2001b). Cutting edge: cellular Fas-associated death domain-like IL-1-converting enzyme-inhibitory protein protects germinal center B cells from apoptosis during germinal center reactions. J. Immunol. 166, 6473-6476.

van Kooten, C., and Banchereau, J. (2000). CD40-CD40 ligand. J. Leukoc. Biol. 67, 2-17.

Vandenabeele, P., Declercq, W., Van Herreweghe, F., and Vanden Berghe, T. (2010). The role of the kinases RIP1 and RIP3 in TNF-induced necrosis. Sci. Signal. 3, re4.

Verbeke, C.S., Wenthe, U., and Zentgraf, H. (1999). Fas ligand expression in the germinal centre. J. Pathol. 189, 155-160.

Verbrugge, I., Maas, C., Heijkoop, M., Verheij, M., and Borst, J. (2010). Radiation and anticancer drugs can facilitate mitochondrial bypass by CD95/Fas via c-FLIP downregulation. Cell Death Differ. 17, 551-561.

Wang, J., and Lenardo, M. J. (1997). Essential lymphocyte function associated 1 (LFA-1): intercellular adhesion molecule interactions for
$\mathrm{T}$ cell-mediated $\mathrm{B}$ cell apoptosis by Fas/APO-1/CD95. J. Exp. Med. 186, 1171-1176.

Wang, J., Lobito, A. A., Shen, F., Hornung, F., Winoto, A., and Lenardo, M. J. (2000). Inhibition of Fasmediated apoptosis by the $\mathrm{B}$ cell antigen receptor through c-FLIP. Eur. J. Immunol. 30, 155-163.

Wang, J., Taniuchi, I., Maekawa, Y., Howard, M., Cooper, M. D., and Watanabe, T. (1996). Expression and function of Fas antigen on activated murine B cells. Eur. J. Immunol. 26, 92-96.

Wang, J., and Watanabe, T. (1999). Expression and function of Fas during differentiation and activation of B cells. Int. Rev. Immunol. 18, 367-379.

Wang, Z., Karras, J. G., Colarusso, T. P., Foote, L. C., and Rothstein, T. L. (1997). Unmethylated CpG motifs protect murine B lymphocytes against Fas-mediated apoptosis. Cell. Immunol. 180, 162-167.

Watanabe, N., Ikuta, K., Nisitani, S., Chiba, T., and Honjo, T. (2002). Activation and differentiation of autoreactive B- 1 cells by interleukin 10 induce autoimmune hemolytic anemia in Fas-deficient antierythrocyte immunoglobulin transgenic mice. J. Exp. Med. 196, 141-146.
Watanabe-Fukunaga, R., Brannan, C. I. Copeland, N. G., Jenkins, N. A., and Nagata, S. (1992). Lymphoproliferation disorder in mice explained by defects in Fas antigen that mediates apoptosis. Nature 356, 314-317.

Wurster, A. L., Rodgers, V. L., White, M. F., Rothstein, T. L., and Grusby, M. J. (2002). Interleukin-4-mediated protection of primary B cells from apoptosis through Stat6-dependent upregulation of Bcl-xL. J. Biol. Chem 277, 27169-27175.

Yoshino, T., Cao, L., Nishiuchi, R., Matsuo, Y., Yamadori, I., Kondo, E. Teramoto, N., Hayashi, K., Takahashi, K., Kamikawaji, N., and Akagi, T. (1995). Ligation of HLA class II molecules promotes sensitivity to CD95 (Fas antigen, APO-1)mediated apoptosis. Eur. J. Immunol. 25, 2190-2194.

Yoshino, T., Kondo, E., Cao, L., Takahashi, K., Hayashi, K., Nomura, S. and Akagi, T. (1994). Inverse expression of bcl-2 protein and Fas antigen in lymphoblasts in peripheral lymph nodes and activated peripheral blood $\mathrm{T}$ and $\mathrm{B}$ lymphocytes. Blood 83, 1856-1861.

Zazzeroni, F., Papa, S., AlgecirasSchimnich, A., Alvarez, K., Melis, T. Bubici, C., Majewski, N., Hay, N., De Smaele, E., Peter, M. E., and Franzoso, G. (2003). Gadd45 beta mediates the protective effects of CD40 costimulation against Fas-induced apoptosis. Blood 102, 3270-3279.

Zhang, H., Rosenberg, S., Coffey, F. J., He, Y. W., Manser, T., Hardy, R. R., and Zhang, J. (2009). A role for cFLIP in B cell proliferation and stress MAPK regulation. J. Immunol. 182, 207-215.

Conflict of Interest Statement: The authors declare that the research was conducted in the absence of any commercial or financial relationships that could be construed as a potential conflict of interest.

Received: 15 April 2012; accepted: 30 June 2012; published online: 25 July 2012.

Citation: Koncz $G$ and Hueber A-O (2012) The Fas/CD95 receptor regulates the death of autoreactive $B$ cells and the selection of antigen-specific $B$ cells. Front. Immun. 3:207. doi: 10.3389/fimmu.2012.00207

This article was submitted to Frontiers in B Cell Biology, a specialty of Frontiers in Immunology.

Copyright (c) $2012 \mathrm{Koncz}$ and Hueber. This is an open-access article distributed under the terms of the Creative Commons Attribution License, which permits use, distribution and reproduction in other forums, provided the original authors and source are credited and subject to any copyright notices concerning any third-party graphics etc. 